Mirella Lingorska*

\title{
Mack the Knife and Knife-Black Dorothy Appositional Metaphoric Compounds: A Comparison and Contrast of the Varying Approaches in Sanskrit Treatises on Grammar and Poetics
}

https://doi.org/10.1515/asia-2017-0068

\begin{abstract}
The present article focuses on appositional metaphoric compounds karmadhāraya-rūpaka in Sanskrit. A first section addresses some problems of compound typology in Western works, where appositional compounds have often been identified as copulative dvandva. Following this general analysis there is a section on appositional compounds from the perspective of the classical Sanskrit grammar, in particular the Pāninian tradition where the metaphorical aspect has not been explored specifically. The final section deals with the contribution of Sanskrit treatises on poetics to the identification of metaphoric compounds and their differentiation from compound similes. The approach suggested in later texts on poetics seems to be based on syntactical criteria, the ambiguity of the double-head topic, i. e. candra-mukha, a moon-face being specified in the comment. According to this, an appositional compound should be analysed as a simile, if the comment refers to the actual part of the compound, i.e. the subject of the simile, or as a metaphor, if the comment refers to the standard of comparison, thus shifting the focus of the sentence from the actual to the imagined entity.
\end{abstract}

Keywords: compounds, metaphors, Sanskrit, poetics, grammar

This article focuses on one type of compounds in Sanskrit, the appositional metaphoric compounds (Skt. karmadhāraya-rūpaka) which are notably interesting for their multilayer structure. On the one hand, through apposition the karmadhäraya (henceforth $\mathrm{kdh}$.) compound relates its single reference to two concepts - a prince regent (also written as prince-regent) is a person who is a

*Corresponding author: Mirella Lingorska, Asien-Orient-Institut, Universität Zürich, Abteilung Indologie, Rämistr. 59, 8100 Zürich, Switzerland. E-mail: mirella.l.grafe@gmail.com 
prince as well as a regent; on the other hand, the rūpaka being a metaphorical device relates a real, actual entity to a fictitious one - a ghost writer (also written as ghost-writer or ghostwriter) is a real writer who is metaphorically predicated with the non-physical feature of a ghost. The combination of these two in the type of the karmadhäraya-rūpaka-s (henceforth kdh.-rup.s) covers only a small group of compounds, but the challenge they present to the analysis of the underlying phrase and its implications make them essential for theories of conceptual combination.

To start with, the title of this article presents an illustration of, first, a wellknown metaphoric compound from Bertold Brecht's ballad Mackie Messer = Mack the knife and, second, a calque of a famous kdh.-example from Patañjali's Mahābhāṣya on Pāṇini 1.2.55: śastrī-śyāmā [devadattā] = knife-black [Dorothy]. ${ }^{1}$ This is to direct our attention to a linguistic phenomenon that is common among the Indo-European languages, even if it occupies different stages of univerbation in the members of the family.

Although the focus of the article is on the above-mentioned Sanskrit formation, an additional contribution of the investigation should be a general clarification of the relation between the appositional compounds and the copulative compounds - two types that are frequently mixed up in modern treatises on linguistics.

As kdh.-rup.s have been treated differently in ancient Indian treatises on grammar, and poetics respectively, a reconstruction of these diverging approaches may have, besides its historical importance, a valuable impact on the general research into the nature of compounds. ${ }^{2}$

1 Precisely speaking, the English rendering Mack the knife rather occupies the intermediate stage between the appositional phrase Mack, the/a knife and the obvious appositional compound in German Mackie Messer. Note that English appositional compounds betray a great variety of graphic representations - parallel to Mack the knife we come across expressions like Eric Slowhand Clapton which is closer to typical compounded appellatives like ghostwriter/ ghost-writer/ ghost writer. On this vid. Guevara/Scalise 2009: 102: “[...] compounds are the morphological constructions which are closest to syntactic constructions, to the point that it is sometimes difficult to distinguish between compounds and phrases."

2 Of course concepts covered by compounds may vary from language to language as demonstrated by the fuzzy transitions from compounds to phrases in the above-mentioned examples, but as Pius ten Hacken argues in 2013: 99 with a view to a translational theory: "It may seem attractive to define compounding on a language-specific basis, because compounds in the same language have more properties in common. They constitute a more homogeneous class, so that it is easier to find criteria that distinguish them. [...], but taking into account other languages may reduce the arbitrariness of the selection of criteria." 


\section{The problem of compound typology in Western treatises on morphology}

\subsection{Appositional compounds}

In the context of Western treatises on morphology, the term "karmadhäraya" has received different explanations; in some cases it is interpreted as a determinative one-head compound (henceforth cmp.) as in blackbird or manchild, and in other especially of the structure noun + noun (henceforth $[\mathrm{N}+\mathrm{N}]_{\mathrm{N}}$ ) as in love-hate - it is considered a subtype of the copulative, a double-head, type which includes also the dvandva (henceforth dv.) -cmp.s. ${ }^{3}$ As a consequence, obvious cases of $[\mathrm{N}+\mathrm{N}]$

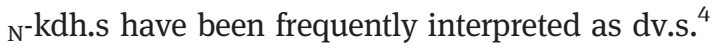

\subsection{Copulative vs. appositional compounds}

In general, the above-mentioned examples with a structure $[\mathrm{N}+\mathrm{N}]_{\mathrm{N}}$ are perceived as syntactically coordinated appositional pairs of nouns, but as they share the feature of coordination with the type of dv.s, they are more often than not confused with them and wrongly subsumed under their category. ${ }^{5}$ Thus, clear cases of kdh.s like earl-bishop, washer-dryer, etc. are dealt with, as if bearing the same referential features like proper dv.s, cf. Austria-Hungary or red-white-blue, etc. ${ }^{6}$

3 For several strategies of presentation vid. Scalise/Bisetto 2009: 38-52. Scalise and Bisetto base their own analysis on the data of the MorboComp project, a data base of cmp.s under development at the Department of Foreign Languages in Bologna. Surprisingly, Sanskrit is not included among the languages tested in the MorboComp/CompoNet projects, vid. Scalise/ Bisetto 2009: 35, FN 1.

4 Cf. Booij 2007: 81; Katamba/Stonham 2006: 333; Fabb 1998: 67; Olsen 2000: 317.

5 Fabb 1998: 67: "There is a third kind of compound, where there is some reason to think of both words as equally sharing head-like characteristics, as in student-prince (both a student and a prince); these are called 'appositional' or 'co-ordinate' or 'dvandva' (the Sanskrit name) compounds."

6 Booij 20072: 81: "Copulative compounds also occur in European languages, as illustrated by the following words:

(9) German Österreich-Ungarn 'Austria and Hungary'

Fürstbischof 'prince and bishop'

English blue-green, washer-dryer

Dutch rood-wit-blauw 'red-white-blue'”. 
Bauer deals explicitly with the category of the kdh.s and supplies an adequate identificational approach, but he too points out the difficulties in differentiating between the two types. ${ }^{7}$

Kastovsky who relies for the Sanskrit material on Hermann Jacobi distinguishes the kdh.-cmp.s from the dv.s on the basis of a diachronic approach, but is not clear enough on the specific features of the kdh.s among the general determinative tatpurușa (henceforth tatp.) -cmp.s, thus giving a clear genitiv tatp., i. e. a house-door, as a kdh.-example. ${ }^{8}$

In their informative article on German appositional cmp.s from 1992 Breindl and Thurmair misleadingly use the term copulative and argue that on morphosyntactic and semantic criteria German copulative cmp.s should be integrated in the group of the determinatives. Apparently both authors oberlook the fact that the kdh.s have been identified as determinatives in the original typology. Moreover, while they discuss the dv.s they are seemingly unaware of the kdh.s althogether. Contrary to its prolific status in Sanskrit word formation, the type $\mathrm{dv}$. is not as widespread in the languages under consideration here where in the most cases it forms the modifying part of a dependent determinative cmp. In examples like mother-child bonding or mind-body problem only the first part mother-child ${ }^{\circ}$ resp. mind-body ${ }^{\circ}$ is a genuine dv., but it does not occur independently. Even occasional real dv.s like G. Schneeregen (=E. snow-rain, i. e. sleet) lack the most crucial feature of Sanskrit dv.s: their non-singular suffix which marks the aggregation of several individual items in the cmp. Characteristically, copulative adjectives like red-white-blue lack the plural marker either which is probably due to their quasi exocentric bias towards the related entity. In the spirit of Patañjali's analysis one could question, whether these three adjectives refer to three different entities, i. e. particulars of redness, whiteness and blueness resp., or to just one entity that is red, white, and blue simultaneously. There are however blends - mostly of surnames - which are indicated as plurals through the predicate, e. g. "'Brangelina' [ = Brad and Angelina] spend £1 million

7 Bauer 2001: 699: "Despite an apparently clear distinction between appositional kdh.-cmp.s and dv., the two are frequently (and understandably) confused [...]”. Unfortunately, even Bauer who uses the Sanskrit vocabulary extensively, misunderstands the typology sometimes, vid. Bauer in his most recent book on compounding 2017: §4.3, p. 65: "The example yellowtail [a type of fish which has a yellow tail] is a noun, but some bahuvrihi compounds are adjectives." In fact all bahuvrihi-s are considered adjectives as they are attributed to their external qualificands. This is obvious in Sanskrit, but it is obscured by the circumstance that in modern languages bahuvrihi-s are mostly - and not seldom metaphorically - nominalised, cf. G. Blaubart; E. bluebeard, It. barbablù.

8 Kastovsky 2009: 332: “(2) Karmadhāraya (also called determinative compounds), e. g. En. blackbird, girlfriend, house-door;”. 
on Banksy work ...".9 Equally "Billary [= Bill and Hillary] - they still run the Democrat Party", ${ }^{10}$ the latter, however, viewed as a single concept when rhetorically exaggerated: "If Billary takes the White House". ${ }^{11}$ These blends of surnames come closest to the original dv.s in Sanskrit which can encompass more than two members under the sole condition that they are coordinated, to quote just one example from the Bhagavadgītā 1.13: "pañava-ānaka-gomukhāh (sahasaiva abhyahanyanta) =Cymbal-drum-trumpet-s (were sounded at once)". ${ }^{12}$

For conventional pairs the traditional Sanskrit grammar provides an additional dv.-type, the samāhära-dv. which occurs as a neutral singular entity. Hence it may be reasonable to interpret mother-child ${ }^{\circ}$ and mindbody $y^{\circ}$ in the above-mentioned determinative cmp.s as subordinate samāhāra-dv.s.

Other strong candidates for the status of independent dv.s in modern Western languages are all compounded numerals, ${ }^{13}$ e. g. twenty-seven, thirty-three, etc., especially paralleled by variants where even the conjunction "and" is retained as in G. siebenundzwanzig, dreiunddreißig, etc. Conspicuously, those have not been examined in morphological treatises on compounding.

From all of the above-mentioned examples, it should become clear that, besides morphological markers like non-singular (i. e. dual or plural) suffixes and syntactic coordination, semantic considerations should be also taken into account before the cmp.'s type can be adequately defined. It is important to highlight one essential point about the semantics of dv.s: in all cases they refer to extensionally distinct entities. Once this is grasped, examples like G. Fürstbischof (= E. Earl-bishop), G. Hosenrock (= E. pant skirt), G. Kindfrau (=E. child-woman, i.e. nymphet or lolita), etc., cannot be counted under the division of $d v$.s as they have just one extensional meaning.

There are, however, some cases where a cmp. may be analysed on pragmatic criteria as either $\mathrm{dv}$. or $\mathrm{kdh}$. involving a specific semantic

9 Cf. http://www.dailymail.co.uk/tvshowbiz/article-487230/Brangelina-spend-1-millionBanksy-work-contemporary-art-auction-London.html (18.09.2017).

10 Cf. http://www.urbandictionary.com/define.php?term = Billary., http://www.independent. co.uk/world/if-billary-takes-the-white-house-a7091186.html (18.09.2017).

11 Cf. http://www.independent.co.uk/world/if-billary-takes-the-white-house-a7091186.html (18.09.2017). It is probably this second example which is responsible for a diverging - and in my view erroneous - classification of the cmp. in Olsen 2000: 312, FN 5: "[...] Billary does not refer to two people any more than e.g. brunch refers to two meals."

12 Vid. Sargeant 1994: 51. Note that the pl.-marker denotes only the cmp., thus supressing the actual number of the members which can be represented with a single item each.

13 Whitney mentions the numerals under the copulative cmp.s in his Sanskrit Grammar under $\S 1261$. For a diverging opinion on Sanskrit numerals vid. Aklujkar 1992: 134, FN 11. Whether cmp.s of numerals are to be considered dv.s or kdh.s should depend on the underlying theory of natural numbers. For the semantic of numerals vid. Ionin/Matushansky 2004. 
interpretation: e.g. love-hate ${ }^{\circ}$ in the phrase love-hate relationship may be either a dv., if the phenomenon described is viewed as an alternation of controversial feelings, or a kdh., if it is felt as one indistinctive ambiguous emotion. $^{14}$

The ambiguity about the appositional cmp.s in general has generated a distortion even in the attempt to understand the original Sanskrit typology. Thus, the misunderstanding of the dv.-concept and the ignorance about the kdh.-concept has led to misleading views on the nature of composition in Sanskrit. Olsen 2000: 302 gives the impression that Sanskrit has no scope for coordinated reference to one and the same individual, i. e. apparently the formation kdh. is not recognised at all. ${ }^{15}$ Moreover, in the analysis of Sanskrit copulatives there is no clear demarcation between appositive coordination vs. asyndetic coordination which might be considered as precursors of kdh.s vs. dv.s. ${ }^{16}$

\subsection{Appositional compounds in Western treatises on Sanskrit grammar}

Unfortunately, the above-mentioned misconceptions might partly go back to earlier treatises on Sanskrit grammar written by Western scholars. So, it is Whitney's Sanskrit grammar, a reference work often quoted by Western scholars (e.g. Bauer, Olsen) which treats the kdh.s - especially of the type $[\mathrm{N}+\mathrm{N}]_{\mathrm{N}}$, - rather briefly, thus implying that it is not always easy to differentiate the appositional cmp.s from the determinative tatp.-cmp.s, of which the appositional form a part. Particularly misleading for non-Sanskritists is the indication that the first part of a $[\mathrm{N}+\mathrm{N}]_{\mathrm{N}}-\mathrm{kdh}$. functions "with a quasi-

14 Bauer 2001: 700 also points out this ambiguity: “[...] it can be difficult to determine the semantics: is a bitter-sweet scent a scent which is defined by being at the intersection of 'bitter' and 'sweet', or one defined by the union of 'bitter' and 'sweet'?"

15 Olsen 2000: 302: "[...] we find that English and German copulatives always denote one individual unless licensed by a specific head. [...] As morphological objects they are lexical units that must pick out an ontologically coherent individual within one of our systems of individuals. The plural denotation of the copulatives in Sanskrit can be explained, on the other hand, by their non-morphological mode of concatenation which has no provision for a singular stem form [...]."

16 Olsen 2000: 304, 314, FN 17. In fact, Sanskrit dv.s appear to be purely asyndetic, the difference between the underlying phrase and the compound being merely the dropping of the inflectional markers for all constituents of the compound but the last one: plakșah

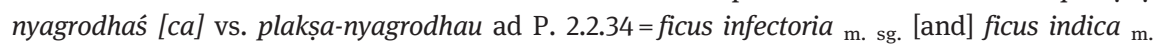
sg. vs. * ${ }^{\prime}$ icus infectoria-ficus indica-s $\mathrm{m}$. du. This demarcation of genuine dv.s as non-singulars does not appear in the Western examples except for the blends considered above. 
adjective value" (Whitney 1924: $§ 1280 d$ ) with reference to the right-hand head. ${ }^{17}$ The kdh.s are considered a subtype of the tatp.s and in tatp.s, the left-hand element typically functions as a modifier of the right-hand head, so it is probably this circumstance which is responsible for Whitney's note.

A very exhaustive and informative exposition of the kdh.s is available in Aklujkar 1992: §33.6. It commences, however, with a similar definition as Whitney's: "The nom[inative] tat[purușa] or tat[purușa] in which the first member is an adj[ective] or functions like an adj[ective] is known as karmadhāraya or descriptive determinative c[ompoun]d. [...]." In my opinion this approach lumps cases like nīlotpala ( = E. blue lotus, Afr. bloublom, blouwaterblom) and mukha-padma (=E. face lotus, G. Gesichtlotus or Lotusgesicht) together which on closer examination prove to have different mechanisms of reference. ${ }^{18}$

A more recent reference work by Tubb and Boose elucidates the rather obscure typology of Pāṇini's Aștādhyāyī by supporting the grammar rules with examples from commentaries on Sanskrit classics. The authors, particularly Tubb in the chapters on nominal composition, explain the definition sutra of the kdh.s via syntactic rendering of the term samānādhikarana: "Karmadhārayas (P 2.1.49 - 2.1.72; 'descriptive compounds', Whitney 1279-1291) are tatpuruṣa compounds in which the two members appear in grammatical apposition in the analysis". ${ }^{19}$ Nevertheless, they refer throughout the whole passage to the referential mechanism of sāmānādhikaranya too: “[kdh.s] are more commonly analyzed with the fuller formula that uses a pronoun to make it clear that both members refer to the same thing [...]". This explanation is probably due to the influence of the analytic method of the commentators who gloss a kdh. $x y$ with a standard formula Skt. $x$ ca tat $y c a=$ this is both $x$ and $y .^{20}$ Tubb and Boose pay a special attention to the kdh.s with underlying simile and to those with underlying metaphor. While their explanation of the first group is based on Pānini's sūtra.s 1.55.2 and 1.55.3, it is difficult for me to see by which criteria the authors

17 This note of Whitney is probably responsible for the misleading translations of several kdh.s in Zimmer 1980: §1280b: rāja-yakșma=king-desease (Whitney 1924: 1280d), but königliche Krankheit, rāja-danta=king-tooth, but königlicher Zahn (Zimmer 1980: §1280b). Formally, these appositional cmp.s cannot be distinguished from the equivalent determinatives, therefore the correct interpretation depends heavily on the context. For rāja-yakșma interpreted unequivocally as kdh. vid. Mallinātha on Māgha's Śiśūpālavadha 2.96 (Māgha 1961): rājā sa eva yakșmeti vā. For rāja-danta interpreted as șașțhi-tatpuruṣa, i. e. king of teeth vid. P. 2.2.31.

18 Vid. Aklujkar 1992: §33.6.

19 Vid. Tubb/Boose 2007: § 1.54, p. 102.

20 Vid. Tubb/Boose 2007: §1.54.1, p. 103. 
identify the rūpaka-cmp.s as they are not explicitly dealt with in the Așțādhyāyī. ${ }^{21}$

In order to clarify this point, it now appears reasonable to turn to the original discussion on kdh.s in the primary sources. As the topic is complex and extensive it deserves a separate close investigation in all of its facets; here I will focus only on the subcategory of simile-kdh.s and metaphoric kdh.s which are based on the former.

\section{Metaphoric appositional cmp.s, i. e. kdh.-rup.s, from the perspective of Sanskrit traditional grammar (vyākarạ̣a)}

At the very beginning of this discussion, it should be borne in mind that the theoretical foundation of the kdh.-cmp.s is somewhat cryptic in Pānini's Aṣțādhyāyī (Pāṇini 1988). The definition sūtra of the kdh.s - 1.2.42 tatpuruṣah samānädhikaraṇah karmadhārayah - is placed before the section properly dealing with cmp.s which starts with 2.1.3 prāk kaḍāāt samāsah. In 1.2.42, the kdh.s are defined as determinative cmp.s, i.e. tatp.s, with the significant peculiarity that the members of the cmp. stay in congruent relation. ${ }^{22}$ The technical term samānādhikaraṇa can have different implications; while samāna itself means same or equal, adhikarana can mean (syntactic) relation as implied by case suffixes, or reference, i. e. the thing-meant or the extension. From this perspective the sūtra can be interpreted under syntactic or under semantic premisses, either as: "an appositional cmp. is a determinative cmp. with syntactically equal [parts]", or as: "an appositional cmp. is a determinative cmp. with the same reference [of its parts]", i. e. whose parts refer to the same object. The apparent ambiguity of the term samānädhikarana might be intentional in the strict economy of the Aștāalhyāyī, because its double meaning serves two important purposes: as a marker of a coordinate syntactic relation it distinguishes the kdh.s from the tatp.s, the latest being subordinate, and as an indicator of a

21 Vid. Tubb/Boose 2007: §1.55.3, p. 108. Of course, the analysis is based on the commentaries of poems, but a question still persists, wheter the commentators have not been influenced more by the poetic theories than by the classical grammar.

22 Vid. Apte 1998: 62, under the lemma adhikarana: “[...] -3 (In gram.) [...] tatpuruṣah samānädhikaranah karmadhārayah P. I. 2, 42 having the members (of the compound) in the same relation or apposition [...]" 
single reference it distinguishes the kdh.s from the dv.s, the latest being always multi-referential. ${ }^{23}$

This particular ability of the kdh.s to combine two concepts in one referent is crucial for our focus as metaphors too relate two predicates to one and the same referent, i. e. a candra-mukha is an object which is referred to both as a moon and a face. The Așțādhyāyī does not delve into the theory of metaphor as the issue is genuinely a semantic one, while the grammar - more precisely the morphology - cannot teach semantics. ${ }^{24}$ But Pānini picks up the matter exactly at that point where it can be handled in the context of word formation. Two sūtra.s - P. 2.1.55 upamānāni sāmānyavacanaị̆ and P. 2.1.56 upamitam vyāghrādibhih sāmānyāprayoge - refer to the formation of kdh.-cmp.s with an underlying simile (upamā). Typically, a simile is described as consisting of a subject of comparison (upamita/upameya), a standard of comparison (upamāna), an expression of the common quality (sāmānyavacana) and a particle of comparison (iva). The above-mentioned sütra.s enable us to form a kdh.cmp. from the standard of comparison and the common quality, or from the subject and the standard of comparison, while the simile marker iva gets lost due to the contraction of the cmp. Patañjali supplies the first variety with the example śastri-śȳamā (=knife-black) and the second one with puruṣa-vyāghra (=man-tiger). As a result of the sāmānādhikaranya condition, we get in the analysis of the first example the sentence śastri devadattā, śyāmā devadattā, but we are not able to derive the meaning of the simile and to detect the common quality between the parts of the apposition Dorothy is a knife, is black. $^{25}$ One way out of this difficulty might be to isolate the $\mathrm{cmp}$., so that both śastrī and śyāmā refer to the extension of śastrī, while the whole cmp. relates a posteriori to the external head devadattā. This seems to be the position of Kayata who corroborates his analysis with the example aśva-karna. As a tatp.

23 Ambiguity of technical terms is not uncommon in Sanskrit grammar or poetics, the different meanings of the very notion 'meaning', i.e. artha, being a paradigmatic example. It seems, however, that throughout the Aștāahyāyī, Pāṇini himself uses the term adhikaraṇa for the referent which is corroborated by the Kāśikāvrọtti on P. 1.2.42: Adhikarana-śabdo'bhidheya-vācī. 24 On different classical approaches to the relation between a word and the entity it denotes vid. the vast discussion of Kātyāyana's vārttika siddhe śabdārthasambandhe lokataḥ in Joshi and Roodbergen 1986: Dev. 20-25. Both authors summarise the conclusions in the translation of these passages: "The relation between the things-meant and the words used to refer to them lies outside the domain of grammar.” Joshi/Roodbergen 1986: 134.

25 The arguments and counterarguments in the analysis of the example are copiously presented and commented to by Joshi and Roodbergen 1971: 87-136. Without abstaining from pointing out the controversies and tacit assumptions in a discussion which encompasses Kātyāyana's, Patañjali's, Kayața’s and Nāgeśabhața’s positions, both authors still remain faithful to Patañjali's spirit and emphasise his opinion. 
it can mean horse ear, but by convention based on similarity between leaves and horse ears it is the name of a particular tree. However, Kayata's proposal is rejected because his analysis is based on a condition called anyapadārtha, i. e. a meaning connected with another word which is prescribed for bahuvrīhi-s and not for kdh.s. ${ }^{26}$ In order to avoid this and other theoretical problems Patañjali remains faithful to P. 1.2.42 and states that even an unspecified quality may be understood through convention as in the expression candra-mukhi devadattā (=moon-faced Dorothy) where the standard of comparison moon may supply the subject of comparison face with various qualities, but actually conveys only the conventional meaning sweet looking = priya-darśana. ${ }^{27}$

On closer examination both suggestions - to interpret śastrīśyāmā either in the spirit of aśvakarna, or of candramukhī - open the door for a metaphoric approach towards the example under P. 2.1.55. First, the contraction of the cmp. results in the loss of the comparison marker, and second, the common quality is understood only implicitly. Both results are typical for a metaphor where the underlying comparison and the common quality are grasped implicitly, hence here at least, we can assume a certain potential for detecting metaphors in the scope of P. 2.1.55.

This is even more the case in P. 2.1.56 - upamitam vyāghrādibhih sāmānyāprayoge - which formulates the rule for forming a cmp. from the subject and the standard of comparison. In P. 2.1.55 the tertium comparationis is part of the cmp. as implied by the definition, although it is difficult to establish the comparison under the restriction of the sāmānādhikaranya condition of P. 1.2.42., but in P. 2.1.56 the tertium comparationis is prohibited (=sāmānyaaprayoga). Contrary to our expectations, the cmp. puruṣa-vyāghra cannot be derived from puruṣo vyāghra iva śūraḥ, because in this case śüra relates to both puruṣa and vyāghra and thus runs against the sāmānādhikaranya condition. The solution to this problem is already suggested by P. 2.1 .55 - both members must refer to one entity, i.e. puruṣa, while the common quality remains unspecified. As a matter of fact, this is the reference procedure of a metaphor and as a consequence of this provision, the wording of P. 2.1.56 could be interpreted as an inverted definition of a rūpaka, where instead of the usual condition of ignoring the difference, rather suppressing the commonness is

26 Cf. Joshi/Roodbergen 1971: Dev. 25 and their comment in the translation of the passage in Joshi/Roodbergen 1971: 102. A question still remains valid whether adjective kdh.s like śastriśyāmā are not subjected to the principle anyapadārtha.

27 anirdiśyamānasyāpi guṇasya bhavati loke sampratyayah / tad yathā / candra-mukhī devadatteti bahavaś candre guṇā yā cāsau priya-darśanatā sā gamyate /, quoted after Joshi/ Roodbergen 1971: Dev. 26. 
stated. In both cases, two otherwise independent concepts are linked to each other by an encompassing phrase. Notwithstanding this possible implication of 2.1.56, Patañjali interprets the example purușa-vyāghra not as a metaphor by puruṣa eva vyāghrah, but as a simile, i. e. puruṣo'yam vyāghra iva. In a similar manner, the Kāśikā analyses well-known examples such as mukha-padma, mukha-kamala, kara-kisalaya as similes, irrespective of their rendering in poetics as metaphors. ${ }^{28}$

Now, what are the conclusions we can draw from the discussion of P. 2.1.55 and P. 2.1.56? The topic of the sütra.s is kdh.-cmp.s based on comparison, which is evident through the defining terms upamāna and upamitam. Through the loss of the comparison marker iva, the cmp.s thus generated cannot be clearly identified as upamā.s, but rahter look like rūpaka.s. The analysis in the commentaries supports this observation, because the sāmānādhikaranya condition requires a common reference, while the inherent comparison can be only implicitly traced through context or usage. It seems also that Patañjali understands the sāmānādhikaranya condition primarily as a reference relation, so one wonders whether this shouldn't be acknowledged as a semantic approach. The reservations of grammatical instruction towards semantics should then probably be reinterpreted with reference to denotation only and not generally to all issues of meaning. In fact, Pāṇini utilises secondary denotation in all sūtra.s concerning contempt (=kșepe), ${ }^{29}$ but nowhere does he go deeper into the nature and method of application of this linguistic function nor is the term rūpaka mentioned in connection with the sūtra.s on comparison. ${ }^{30}$ At the end of the discussion by the grammarians, we are left with no safe procedure to distinguish whether a comparison or a metaphor is underlying a kdh.-cmp. of the type

28 Kāśikāvrọtti ad P. 2.1.56 (1965: 75): puruṣo’yam vyāghra iva puruṣaḥ vyāghrah // puruṣasiṃhah/ [...] vyāghra / siṃha / roș̣a / rṣabha / candana / vrkșa / vrșa / varāha / hastin / kuñjara / ruru / prșata / puṇdarīka / balāhaka / ākrti-gaṇaś cāyaṃ / tenedam api bhavati mukha-padmam, mukha-kamalam, kara-kisalayam, pārthiva-candrah ity evam-ādi//.

29 Such as under P. 2.1.26; 42, i. e. tìrtha-dhvānikșa, tìrtha-kāka (= [sacred-bathing-place]-crow) which metaphorically means a very greedy person.

30 Interestingly, the term is introduced by the editors Joshi and Roodbergen: "Patañjali does not give the literal meaning of the cp. (i. e. the sense of rūpaka: 'metaphor'), but the implied meaning (i. e. the sense of upamānopameyabhāva). It has already been pointed out in the case of śastriśsyamā devadattā, that, from the grammatical point of view, the expression must be taken as rūpaka: 'the man is a tiger"'. Joshi/Roodbergen 1971: 132. For a position altogether negative with reference to the acceptance of rūpaka in early vyākarana cf. Bhattacharya 1982: 61: "[...] in the earlier literature there was no separate existence of rūpaka apart from upamā and so there was no provision for rūpaka-karmadhāraya in Pānini. Kātyāyana and Patañjali did not make any specific mention of rūpaka-samāsa”. 
puruṣa-vyāghra or mukha-padma, although the latter is widely discussed and analysed in treatises on poetics. ${ }^{31}$

Before we turn now to the sources of the alankāra-śāstra on the kdh.-rup.s, let us consider - rather speculatively - one further Pāninian device which could give us an additional clue for interpreting the $[\mathrm{N}+\mathrm{N}]_{\mathrm{N}}-\mathrm{cmp} . \mathrm{s}$ as metaphors.

The issue of predominance of meaning in the cmp. is regulated by Pānini through the notion of upasarjana. This technical term refers to the subordinate constituent or to the modifier in the cmp., and its distribution is defined by P. 1.2.43 prathamā-nirdiștam samāsa upasarjanam, which refers to the indication of the modifier by the rules of compounding, and by P.2.2.30 upasarjanam purvam, which determines the placement of the modifier in the initial position. Both rules establish the right-hand constituent as a head in puruṣa-vyāghra, mukha-padma, mukha-kamala, etc. to which the left-hand constituent adds a further qualification. The upasarjana condition is easier understood in examples of dependent determinatives, where the subordination of the first element to the second seems trivial, i. e. rāja $a^{\circ}$ in rāja-purușa does not refer to a king, but modifies in a certain manner the meaning of the principle (= pradhāna) constituent puruṣa. Patañjali does not accept the impact of the upasarjana rules on the kdh. purușa-vyāghra, etc. He argues that in this case upasarjana should be taken in its non-technical sense, so that purușa ${ }^{\circ}$, despite being referred as a nominative by the formation rule P. 2.1 .56 (i. e. upamitam) and in spite of its initial position in the cmp., still remains the predominant element. While it is not exactly clear how to apply the rule of upasarjana in kdh.s where both nouns stay in apposition, it is only logical that in metaphoric cmp.s where the topic shifts from the direct denotation to the secondary, i. e. figurative one - it is precisely the figurative and not the direct noun which should occupy the right-hand position given the prevailing right-headedness of Sanskrit cmp.s. ${ }^{32}$ On

31 For the analysis of a famous example vid. Mallinātha on Kālidāsa's Meghadūta (Kālidāsa 1993): megha eva dūtah megha-dūtah = the cloud exclusively is a messenger / it is the cloud, who is a messenger by which the complete identification of the subject with the standard of comparison is achieved.

32 On the other hand, the order is obviously reversed in the above-mentioned rāja-yakșma, räja-danta, etc., where the right-hand element is the actual one, while the initial element is metaphoric. For a similar distribution of the figurative vs. non-figurative denotation vid. popular cmp.s like car'-kolokol (Russ.) = king-bell, car'-puška=king-cannon. It may be reasonable in this case to look for a degree of formalisation as in frozen metaphors vs. fresh poetic creations. So in German, where right-headedness is also prevailing, idiosyncratic poetic metaphors seem to place the metaphoric constituent on the right, while conventional metaphoric cmp.s have it on the left, cf. Kalif Storch = the Caliph Storck from Wilhelm Hauff's literary fairy tale "How the Caliph became a Storck" vs. Froschkönig=the frog king in a folk tale. In this context it may be also is advisable to distinguish between the formal, i. e. morphological, and the semantic head. Vid. Guevara/Scalise 2009: 112, 113. 
this criterion, ${ }^{\circ} v y \overline{a g h r a}$ and not puruș $a^{\circ}$ should be considered predominant. As a matter of fact, this view resembles to a large extent the concept of rūpaka in the treatises on poetics.

\section{Kdh.-rup.s from the perspective of Sanskrit traditional poetics (alañkāra-śāstra)}

The field of implicit or metaphorical meaning is very extensive and has been studied from various points of view in different branches of Sanskrit scholastic thought. Even the smaller topic of the trope rūpaka has been examined in detail by numerous authors. For the purpose of the present paper, only a kind of a model can be offered which will attempt - in spite of the inevitable simplification - to cover the most salient features of the trope. Moreover, in accordance with the subject matter of the article only the compounded rūpaka will be considered.

In his survey on the history of ruppaka (henceforth rup.) Biswanath Bhattacharya has shown that the trope has been an object of study and enumeration of subtypes from the very beginning of alankkāra-śāstra. ${ }^{33}$ Bharata mentions it as one of his four pricipal alaikearra.s along with upamā (henceforth up.), dippaka and yamaka. Notwithstanding different shades of meaning and taxonomies throughout the history of the trope, the essential relation to up. remains unequivocal. The early authors on poetics seem to share the inclination of the grammarians in emphasising the comparison aspect of rup., thus Dandin, while introducing rup. in Kāvyādarśa, 2.66 (Daṇdin 1924), states that it is nothing else than up.: upamaiva tirobhuta-bhedā rūpakam ucyate/= it is simile with a suppressed difference which is called rūpaka. Kdh.-examples illustrate the compounded, i. e. samasta-type of the trope: bāhu-latā (=an arm-a creeper), pāni-padma (=a hand-a lotus), carana-pallava $=($ foot- $a$ sprout $)$. However, the emphasis on the simile through the particle eva in the definition creates an uncertainty whether the examples should be interpreted as up.s or as rup. ${ }^{34}$ to such a degree that some

33 Cf. B. Bhattacharya 1982 where the author presents a vast number of records on rup., not only - as stated in the title - derived from sources on poetry, but from the grammar tradition too.

34 That this uncertainty persists throughout the centuries is visible in standard Skt. dictionaries such as Apte’s, Monier-Williams’ or Böhtlingk's. Apte in 1998: 1165 renders bāhu-latā, first, as a simile, and second, as a right-head cmp. in contrast to the analysis of puruṣa-vyāghra: bāhulat $\bar{a}=$ an arm-like creeper, however cf. bāhu-daṇ $a=a$ long, staff-like arm which is in agreement with puruṣa-vyāghra. Apte does not list pāni-padma, but pāni-pallava as a sprout-like hand or the fingers; similarly, all kdh.s with caraña in initial position are resolved as similes: ${ }^{\circ}$ aravindam, ${ }^{\circ} \mathrm{kamalam},{ }^{\circ}$ padmam = a lotus-like foot. Monier-Williams in 1976: 730 is moving slightly 
commentators need additional support via context to decide whether bāhu-latā is an arm-like creeper, or a creeper-like arm, or an arm-creeper, or a creeper-arm. ${ }^{35}$ In a very recent study on Kashmiri poetics Yigal Bronner points out these diverging tendencies in the treatment of kdh.-cmp.s: while Vāmana denies the underlying rup. in formations such as candra-mukha, Udbhața introduces rup. in the analysis of the type mayūra-vyamsaka. ${ }^{36}$ The problems of analysis here revolve around the estimation of identity between the subject and the standard of comparison and mirror the successive stages of development from equation of qualities dharmasāmya up to the full identification of the two entities sāyujya. Bhattacharya describes these with the corresponding terms tādrūpya and tādātmya and points out that up to Appayya Dìkșita both terms were used without sharp discrimination and sometimes even synonymously. ${ }^{37}$ However, the difficulties in theoretically grasping the phenomenon which probably arose from a certain ontological attitude towards language did not prevent poets from making full use of kdh.-rup. Once initiated, the mechanism of superimposition of further images could be processed until a completely new fictitious scenery appeared before the eyes of the responsive connoisseur: your eye-brow, a dancer performs a dance- $a$ charming play on the lotus-stage, [your] face= mukha-pankaja-range'sminn bhrūlatā-nartakī tava līlā-nrttaṃ karoti as in Dạ̣ḍin’s Kāvyādarśa 2.93 (Daṇdin 1924). Bronner calls this 'rūpaka's multilayered ornamental process' and quotes a beautiful illustration from Udbhața’s Kāvyālaṃkārasārasaṃgraha 1.13, example No. 11:

\author{
jyotsnā'mbune'ndu-kumbhena tārā-kusuma-śāritam / \\ kramaśo rātri-kanyābhir vyomo'dyānam asicyata // \\ Pouring moonlight-spray \\ from their Luna-jar,
}

towards rup. with bāhu-latā translated as an arm (lithe as a) creeper and Böhtlingk in 1990: 82 is very cautious to exemplify even the psycho-linguistic undercurrent behind the metaphoric turn in rendering bāhu-latā as der als Ranke gedachte Arm.

35 In his vyākhyā to Kāvyādarśa Rangācārya Śāstri (Daṇḍin 1938) supplies Daṇḍin’s definition of rup. with another example mukha-padma and analyses this according to the context - in case the predicate refers to the upameya, the $\mathrm{cmp}$. is a simile, if the predicate refers to the upamana, the cmp. is a rup. This procedure must be older, because it can be found in Mammața's Kāvyaprakāśa.

36 Vid. Bronner 2016: 93-94: “[...] Vāmana [...] denied outright that rūpaka could even exist inside compounds [...] All this was to change with Udbhața [...] it was also he who decisively cut the Gordian grammatical knot that tied rūpaka to compounds expressing similitude by identifying a different Pāninian noun-noun compound type, the mayūra-vyamsaka or "picaroonpeacock' variety, as its locus." For the whole argument with various pros and cons cf. also Bhattacharya 1982: 60-61; 350-358.

37 Vid. Bhattacharya 1982: 37-38. 
the night-maidens gradually

watered the sky-garden,

whose blossoms are stars. ${ }^{38}$

Mammața comments on a similar example of a complex rup. (samastavastu-vișaya-rup.) with reference to the interpretation of the cmp.s, first, as metaphors and, second, in favour of the fictive (=aprakrta or aprakaranika or aprastuta) member of the cmp. (Mammața 1965: 595):

jyotsnā-bhasma-cchuraṇa-dhavalā bibhratī tārakāsthī

ny-antar-dhāna-vyasana-rasikā rātri-kāpālikìyam /

dvīpād dvīpaṃ bhramati dadhatī candra-mudrā-kapāle

nyastaṃ siddhāñjana-parimalaṃ lāñchanasya cchalena// (Kāvyaprakāśa, 10.93 [421])

Here the main kdh. rātri-kāpālikī (=night-female ascetic) is analysed as rup., because the attribute antar-dhāna-vyasana-rasikā can refer only to a sentient individual, i. e. to the female ascetic, but not to the night $>$ this night - an ascetic [...], who likes to amuse herself by disappearing, roams from continent to continent [...]. The authorities on poetic matters argue that the analysis is accomplished according to Pāninini 2.1.72: mayūra-vyamsakādayah. ${ }^{39}$ This sūtra actually introduces a list of irregularly formed (and rare) tatp.s, without giving any theoretical explanations for the formation of the listed cmp.s, where some of them are rather untypical for Sanskrit, e. g. the verbal cmp. prehi-kardama $=$ mud-go-away, a designation of a rite, in which no impurity is allowed. Here again, the impression arises that the grammar tradition (vyākarana) does not make any provisions for the metaphoric cmp.s, with their inclusion in P. 2.1.72 being rather a construction of the authors of poetics. ${ }^{40}$

38 Vid. Bronner 2016: 106 (my hyphenation of the Skt. cmp.s). Bronner discusses in detail the shortcuts of a translation into a language where the condensed images and particular puns of Sanskrit cannot be sufficiently conveyed, but this vers exemplifies an additional problem: it is more probable that rātri-kanyāh $=$ night-maidens would be automatically understood as a tatp.cmp. maidens of night than as the intended kdh.-cmp. maidens who are nights or nights that are maidens.

39 For a detailed discussion of the argument vid. Kāvyaprakāśa of Mammața with the Sanskrit Commentary Bālabodhinī by V. R. Jhalakikara (Mammața 1965). A summary is found also in Gajendragadkar 1970: 287: “[...] the dissolution of the compound and consequently the figure are determined by some other word in the sentence [...]. Such decisive word [...] is antar-dhāna-vyasanarasika $[\mathrm{which}]$ is characteristic of the upamāna viz. kāpālike [...]. Therefore, the compound must be so dissolved as to give prominence to kāpālikī. This is done by dissolving it as rātrir eva kāpālikī." 40 Cf. Bhattacharya1982: 61: "It is only the ālanikārikas like Udbhața, Hemacandra, Mallinātha, Nāgeśa, etc. that referred to the mayūra-vyaṃsakādi group of anomalous tatpuruṣa-samāsa and made a compromise between the Alañkāra-śāstra and grammar. Rūpaka-karmadhāraya is thus 
We come across a similar suggestion in Kale (1988: $\S 221$, Note 2, FN): if a $\mathrm{kdh}$. has a predicate which is referring to the subject of comparison (upameya), thus emphasising the topic of the underlying sentence, the $\mathrm{cmp}$. should be resolved as an up., i.e. mukha-padmam sahāsyam (=the face-lotus smiles) > mukham padmam iva (=the face is like a lotus), where sahāsyam can refer directly only to mukham. If the $\mathrm{kdh}$. has a predicate in the further context which can only indirectly refer to the subject, while directly referring to the standard of comparison, the cmp. should be resolved as rup., i. e. mukhapadmam vikasitam (=the face-lotus blossoms) > mukham eva padmam. ${ }^{41}$ In this case, the full identification of both subject and standard of comparison has taken place and the narrative is now focused on the figurative topic. Speculatively, we can interpret the last point as a licence to superimpose the non-actual qualities of the upamāna upon the upameya, thus introducing the latter into the fictional discourse of metaphor.

It is difficult to convey the suggestive and performative power of the compounded figure of identification in a language which lacks this kind of transformation mechanism. The vividness of imagery conveyed thus by speech acts reminds one of the enactment of poetical plots which may also be called rūpaka, and helps to understand why both visual and audible performance are put under the same heading of kāvya in the Sanskrit theory of poetic composition.

In contrast to the grammarians, the authors of poetics are interested in the examination of the semantic process through which the denotation of one constituent of the $\mathrm{kdh}$. is superimposed (=äropita) on the denotation of the other constituent, which further leads to the substantial equivalence (tādātmyatā) of the two entities. This process of engulfment of the upameya by the upamāna establishes a multilayer context of reference which can hardly be handled with the means of any epistemologically biased attitude towards language. Quite in contrast to any claim of fundamental truth, the trope rup. ${ }^{42}$ seems to function as a key for fictitious narratives which are not under the

a creation of some later ālaṅkārikas in conformity with grammar.” However, see again FN 19 above for Kāśikā rọtti listing some well-known rup.s under P. 2.1.56.

41 Kale's method of analysis must rely on older procedures, cf. FN 35 supra for the same analysis by Rangācārya Śāstri ad Kāvyādarśa 2.66.

42 One famous specimen of Sanskrit kāvya illustrates this very well. In Meghadūtam Kālidāsa himself poses the question: dhūma-jyotih salila-marutām sam-nipātah kva meghah / saṃdeśärthạ kva pațukaranaih prānibhih prāpaniyah / - and makes the imaginary passage of the cloud-messenger only possible in the double key of a lovelorn daydream and a poem (Kālidāsa 1993). 
command of ritually powerful language. ${ }^{43}$ Confronted with vyākarana whose occupation with correct and unambiguous speech with strong truth demands originates in the ritual, all kinds of deviating language usage are considered undesirable or at least problematic. For this reason the poetic efforts towards a polysemic discourse which is insensitive to claims of truth, are rather unpopular with the proponents of other linguistic views and have been often exposed to critical debates. ${ }^{44}$

\section{Conclusion}

The piece of research behind this paper has been sparked by a very modest initial interest in the nature and function of appositional $[\mathrm{N}+\mathrm{N}]_{\mathrm{N}}$-cmp.s with underlying rup. - an interest that should be easily comprehended by anyone working in the field of Sanskrit poetry. The attempt to find support in the commentaries showed that there were no quick solutions available to seemingly unsophisticated formations such as mukha-padma or chandra-mukha. Often, commentators have built their strategies upon grammatical rules that were not transparent. The investigation of the contributions of the Pāninian grammarians left the impression that $[\mathrm{N}+\mathrm{N}]_{\mathrm{N}}$-kdh.s were somehow tacitly perceived as rup.s, although theoretically defined as up.s. The sources on poetics presented variegated approaches - some faithful to the grammatical tradition, others inventive and insightful.

Apart from the Indian tradition, appositional compounds with the structure $[\mathrm{N}+\mathrm{N}]_{\mathrm{N}}$ have been a controversial subject in the Western treatises on morphology. As my interest in the topic has not been purely historic, there was an expectation from the very beginning that a better understanding of the Sanskrit material could facilitate the present-day discussion on compounding and dispel some misconceptions. An additional specific perspective on metaphoric reference gained by considering the strategies of Sanskrit classical poetics could offer a valuable contribution to the theory of fictional discourse.

43 Of course the figure of metaphoric identification is not the only one utilising the potential of figurative speech. The Sanskrit poetics offer through the notion of dhvani a full-fledged theory of fictional discourse which reaches far beyond the scope of a single figure of speech.

44 For a detailed discussion of the non-epistemic nature of poetic speech against the background of Mīmāṃsā and Nyāya vid. Ānandavardhana in Dhvanyāloka 3.33 (Ānandavardhana 1974). 
Acknowledgements: For comments and suggestions I am grateful to Frank Köhler, Ronjit Medda and Leonid Kulikov. I also want to thank Kevin James Mann and Madeesh Kannan who improved my English style.

\section{References}

Aklujkar, Ashok (1992): Sanskrit: An Easy Introduction to an Enchanting Language. Vol. 1\&2. Richmond: Svādhyāya Publications.

Ānandavardhana (1974): The Dhvanyaloka of Anandavardhana: Critically Ed. With Introd., Transl. And Notes. Ed. and transl. by Kelarupa Krishnamoorthy. Dharwar: Karnatak Univ.

Apte, Vaman Shivaram (1998): The Practical Sanskrit-English Dictionary, Revised and enlarged edition. Kyoto: Rinsen book company.

Bauer, Laurie (2001): “Compounding”. In: Language Typology and Language Universals, Vol. I. Edited by Martin Haspelmath. Berlin: Walter de Gruyter, 695-707.

Bauer, Laurie (2017): Compounds and Compounding. New York: Cambridge University Press.

Bhattacharya, Biswanath (1982): A History of Rūpaka in the Alañkāra-Śāstra. Varanasi: Chaukhambha Orientalia.

Böhtlingk, Otto, Roth, Rudolf (1990): Sanskrit-Wörterbuch. Fünfter Theil. Delhi: Motilal Banarsidass Publishers.

Booij, Geert $\left(2007^{2}\right)$ : The Grammar of Words. Oxford: Oxford University Press.

Breindl, Eva, Thurmair, Maria (1992): "Der Fürstbischof Im Hosenrock”. Deutsche Sprache 1: 32-61.

Bronner, Yigal (2016): “Understanding Udbhața: The Invention of Kashmiri Poetics in the Jayāpīḍa Moment". In: Around Abhinavagupta. Aspects of the Intellectual History of Kashmir from the Ninth to the Eleventh Century. Edited by Eli Franco and Isabelle Ratié. Berlin: Lit Verlag, 81-147.

Daṇḍin (1924): Kāvyādarśa of Daṇ̣in: Sanskrit Text and English Translation. Ed. and transl. by Sripad Krishna Belvalkar. Poona: The Oriental Book-supplying Agency.

Daṇ̣̣in (1938): Kavi-Pravareṇācārya-Daṇ̣̣inā Viracitạ̣ Kāvyādarśaḥ. Vidyābhūṣaṇena Vairājakṣetra-Vāsinā Raḍ̣̣̂i-Kulāvataṃsena Bāla-Krș̣nācārya-Tanujena PaṇditaRangācārya-Śāstrinā Viracitayā Prabhākhyayā Vyākhyayā Sametah. Poona: Bhandarkar Oriental Research Institute.

Fabb, Nigel (1998): “Compounding”. In: Handbook of Morphology. Edited by Andrew Spencer and Arnold M. Zwicky. Oxford: Blackwell, 66-83.

Guevara, Emiliano, Scalise, Sergio (2009): "Searching for Universals in Compounding". In: Universals of Language Today. Edited by Sergio Scalise, Elisabetta Magni and Antonietta Bisetto. Dordrecht: Springer, 101-128.

Ionin, Tania, Matushansky, Ora (2004): “A Singular Plural”. In: WCCFL 23 Proceedings. Edited by Benjamin Schmeiser, Vineeta Chand, Ann Kelleher and Angelo Rodriguez. Somerville, Mass.: Cascadilla Press, 101-114.

Jacobi, Hermann (1897): Compositum Und Nebensatz: Studien Über Die Indogermanische Sprachentwicklung. Bonn: Verlag von Friedrich Cohen. (Zit. in Kastovsky 2009).

Joshi, Shivram Dattatray, Roodbergen, Jouthe A. F. (1971): Patañjali’s Vyākaraṇa-MahābhāṣyA. Karmadhārayāhnika (P. 2. 1.52-2.1.72), ED. With Translation and Explanatory Notes by 
S. D. Joshi and J. A. F. Roodbergen. Poone: University of Poona. (NB triple pagination: i-xxviii, Devanagari 1-58, 1-275).

Joshi, Shivram Dattatray, Roodbergen, Jouthe A. F. (1986): Patañjali’s Vyākaraṇa-MahābhāṣyA. PaspaśähnikA. Introduction, Text, Translation and Notes by S. D. Joshi and J. A. F. Roodbergen. Pune: University of Poona. (NB triple pagination: i-xxiv, Devanagari 1v41, 1-237).

Kale, Moreshwar Ramcandra (1988): A Higher Sanskrit Grammar: For the Use of School and College Students. Delhi: Motilal Banarsidass.

Kālidāsa (1993): The Meghadūta of Kālidāsa: Text with Sanskrit Commentary of Mallinatha, English Translation, Notes, Appendices and a Map. Ed. And Transl. By Moreshwar Ramcandra Kale. Delhi: Motilal Banarsidass Publishers.

Kastovsky, Dieter (2009): “Diachronic Perspectives”. In: The Oxford Handbook of Compounding. Edited by Rochelle Lieber and Pavol Štekauer. Oxford: University Press, 323-340.

Katamba, Francis, Stonham, John $\left(2006^{2}\right)$ : Morphology. Hampshire: Palgrave Macmillan.

Māgha (1961): Mahākavi-Śrī-Māgha-Pran̄itam Śiśūpālavadham. Mahopādhyāya-Śrī-MallināthaKrTa-Sarvańkașā-Vyākhyā-Yutaṃ Maṇiprabhā-Nāmaka-Hindī-Ṭikā-Sahitam. Vārāṇasī: Caukhambā Vidyābhavana.

Mammața (1965): Kāvyaprakāśa of Mammața with the Sanskrit Commentary Bālabodhini by Vāmanācārya Rāmabhaț̣a Jhalakīkara. Edited by Raghunath Damodar Karmarkar. Poona: Bhandarkar Oriental Research Institute.

Mammața $\left(1970^{3}\right)$ : The Kāvyaprakāśa of Mammața: First, Second, Third and Tenth Ullasas, Ed. With an Introduction, Translation into English, Notes (Explanatory, Critical, Comparative and Historical). Ed and Transl. By Aswathama Balacharya Gajendragadkar. Bombay: Popular Prakashan.

Monier-Williams, Monier (1976): A Sanskrit-English Dictionary etymologically and philologically arranged with special reference to cognate Indo-European languages. Oxford: Clarendon Press.

Olsen, Susan (2000): "Copulative Compounds: A Closer Look at the Interface between Syntax and Morphology”. In: Yearbook of Morphology 2000. Edited by Geert Booij and Jaap Van Marle. Dordrecht/Boston/London: Kluwer Academic Publishers, 279-320.

Pāṇini (1988): The Aștāanhyāyī of Pāṇinl. Vol. I. Ed and Transl. by Chandra Śrīśa Vasu. Delhi: Motilal Banarsidass Publishers.

Sargeant, Winthrop (1994): The Bhagavad Gītā. Transl. by Winthrop Sargeant. Albany: State University of New York Press.

Scalise, Sergio, Bisetto, Antonietta (2009): “The Classification of Compounds”. In: The Oxford Handbook of Compounding. Edited by Rochelle Lieber and Pavol Štekauer. Oxford: University Press, 34-53.

Ten Hacken, Pius (2013): "Compounds in English, in French, in Polish, and in General". SKASE Journal of Theoretical Linguistics 10.1: 97-113 The Slovak Association for the Study of English \& University Library of Prešov University.

Tubb, Gary A., Boose, Emery R. (2007): Scholastic Sanskrit. A Handbook for Students. New York: American Institute of Buddhist Studies.

Vāmana / Jayāditya (1965): Jinendrabuddhi-Pāda-Viracitayā Nyāsāpara-Paryāya-KāšikāVivaraṇa-Pañjikayā Haradatta-Miśra-Viracitayā Padamañjarī-Vyākhyayā Ca Sahitā Śrīmad-Vāmana-Jayāditya-Viracitā KāśikāvrọTtịh. 2. Bhāga. Vārāṇasī: Prācya Bhāratī Prakāśan. 
Whitney, William Dwight (1924): Sanskrit Grammar. Including Both, the Classical Language and the Older Dialects of Veda and the Brahmana, Fifth edition, Repr. 1995, 2003. Delhi: Low Price Publications.

Whitney, William Dwight (1980): Indische Grammatik: Umfassend Die Klassische Sprache Und Die Älteren Dialecte. Aus dem Englischen übersetzt von Heinrich Zimmer. Wiesbaden: Breitkopf \& Härtel. 